\title{
Clean Cities Around the World
}

Modeled after the U.S. Department of Energy's (DOE) Clean Cities partnership, Clean Cities International (CCI) aims to facilitate the exchange of information on alternative fuels in the transportation sector to interested countries around the globe. The environmental benefits of using alternative fuels are clearall can profit from cleaning the air, producing and using fuels domestically, and enhancing local economic activity. CCI seeks to use the successful experience in North America to help international communities realize these benefits.

CCI works with foreign governments, industry, and nongovernmental organizations to help establish foundations for viable alternative fuel markets, ensuring safe and quality performance. CCI has already partnered with several countries, and more partnerships are on the horizon.

\section{Background}

Clean Cities takes a unique, voluntary approach to alternative fuel vehicles (AFV) development, working with coalitions of local stakeholders to help develop local strategies and initiatives to integrate AFVs into the local transportation sector. Clean Cities works with the public and private sectors and individuals to help them establish foundations for alternative fuel markets and encourage others, primarily fleets, to see AFVs as a viable option to integrate with the mainstream transportation sector. By encouraging AFV use, Clean Cities helps to achieve energy security and environmental quality goals on local, national, and international levels. In the United States, 88 coalitions have been designated by DOE.

\section{Successful Activities}

To date, Clean Cities International has worked with officials from Bangladesh, Brazil, Chile, China, Costa Rica, Egypt, the European Union, Guatemala, India, Mexico, Nepal, Peru, the Philippines, and Trinidad \& Tobago on alternative fuel transportation issues.

Working with CCI engages countries at different levels of involvement, from official designation of a city,

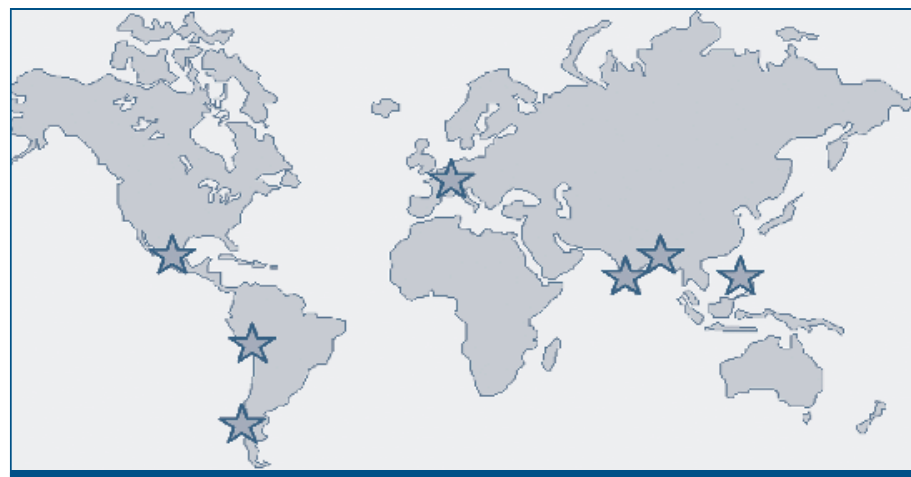

Current Clean Cities International Activities

such as in Santiago; to AFV training programs in Delhi; to assessments of emerging markets in Manila; program plan development in Mexico City; review of codes and standards in Dhaka; and peer exchange with the European Commission CIVITAS program. CCI aims to help each country assess its specific situation to see how the program can best offer its strengths and services to aid that country.

\section{Importance of Partnerships}

With nearly a decade in the domestic and international arena, CCI recognizes the crucial roles that many of its partners have played in successful projects. CCI has cultivated strong, long-term relationships with U.S. equipment and engine manufacturers that lend expertise in determining market opportunities in the international marketplace and supply several cost-share initiatives. Successful foreign partnerships through the CCI program have developed key international contacts in the transportation sector and additional local cost share.

In cases where CCI has lacked sufficient funds to meet the needs of an international partner, the program's compelling capacity to leverage funding with U.S. and multilateral financing organizations has yielded maximum utilization of available funds. CCI has successfully leveraged funds anywhere from $\$ 500$ to millions of dollars, for example, from the U.S. Agency for International Development, including Missions in 
Dhaka, Delhi, and Manila, U.S.-Asia Environmental Partnership, National Energy Technology Laboratory, U.S. Department of Commerce, U.S. Trade and Development Agency, and many private companies.

\section{Some notable accomplishments to date:}

- The first international "clean city" was established in Santiago, Chile.

- CCI has fostered stakeholders and coalition development in India with the Indian Auto LPG Coalition (IAC).

- CCI educated nearly 860 technicians, drivers, policy- makers, and educators on AFVs, stations, emissions, and policies to ensure effective and safe programs.

- CCI educated over 120 people from 12 countries on U.S. trade and technology tours to increase partnership opportunities for business and industry, and promote global adoption of AFVs.

- CCI has sent technical experts all over the world, e.g., to review Bangladesh codes and standards to encourage safer use of natural gas in transportation, and conduct an alternative fuel station assessment and gauge potential use in Manila.

- CCI cosponsored a mini-trade show on U.S. AFV technologies in Dhaka.

- CCI has hosted workshops on "How To Join Clean Cities" at National Clean Cities conferences and in Bangladesh, Mexico, and the Philippines.

\section{Plans for the Future}

CCI receives many requests for assistance each year and has devised criteria to focus activities in emerging markets, helping to ensure high levels of success, and allocating limited program resources.

To guide coalitions on how to form their own Clean Cities program, CCI provides a framework for coalitions to develop a strategic program plan and partnerships to expand the local AFV market by encouraging

\section{Prepared by Science Applications International Corporation (SAIC)}

\footnotetext{
Sponsored by the U.S. Department of Energy

Energy Efficiency and Renewable Energy

Office of Weatherization and Intergovernmental Programs

For more information contact: EERE Information Center

www.eere.energy.gov/informationcenter

A Strong Energy Portfolio for a Strong America

Energy efficiency and clean, renewable energy will mean a stronger economy,

a cleaner environment, and greater energy independence for America. Working

with a wide array of state, community, industry, and university partners, the

U.S. Department of Energy's Office of Energy Efficiency and Renewable Energy

invests in a diverse portfolio of energy technologies.

DOE/GO-102005-2219 • November 2005
}

\section{Santiago: The First International Clean City}

In 1999, DOE offered to share the Clean Cities model with the city of Santiago, Chile. Santiago was poised to benefit from the model because of its strong economy and because the first natural gas pipeline running from Argentina to Chile was completed in late 1995. In the ensuing years, $\mathrm{CCl}$ sent personnel to Santiago to support the government of Chile in establishing a Clean Cities coordinator and coalition with cooperation from U.S. industry. Officials from Santiago and its sister city, Chicago, Illinois, signed a Memorandum of Understanding (MOU) agreeing to proactively share information about each city's progress. In 1999 and 2001, Chilean delegations participated on trade missions to the United States that showcased natural gas transit bus and airport technologies. As a result in 2000, the Chilean National Environmental Commission and the Office of the Governor of Santiago implemented a $\$ 1.2$ million subsidy to purchase natural gas buses. To date, there are over 4,900 natural gas vehicles and 12 stations in Chile, and the coalition is self-sustaining.

each stakeholder to commit to activities that strengthen the AFV market. This framework, called the "Clean Cities International Roadmap," includes six steps coalitions can take to emulate the CCI model:

Step 1. Form a Coalition and Hold Stakeholder Meetings

Step 2. Appoint a Coordinator

Step 3. Establish Stakeholder Commitments

Step 4. Develop a Program Plan

Step 5. Celebrate Membership

Step 6. Implement the Program Plan

Developments and activities in the international arena can be tracked on the CCI web site below.

\section{For more information, you can:}

Visit the Clean Cities International web site at www.eere.energy.gov/cleancities/international, or call the EERE Information Center at 1-877-337-3463.

\section{Prepared by the National Renewable Energy Laboratory (NREL) \\ NREL is a U.S. Department of Energy National Laboratory \\ Operated by Midwest Research Institute $\cdot$ Battelle}

Neither the United States government nor any agency thereof, nor any of their employees, makes any warranty, express or implied, or assumes any legal liability or responsibility for the accuracy, completeness, or usefulness of any information, apparatus, product, or process disclosed, or represents that its use would not infringe privately owned rights. Reference herein to any specific commercial product, process, or service by trade name, trademark, manufacturer, or otherwise does not necessarily constitute or imply its endorsement, recommendation, or favoring by the United States government or any agency thereof. The views and opinions of authors expressed herein do not necessarily state or reflect those of the United States government or any agency thereof.

Printed with a renewable-source ink on paper containing at least $50 \%$ wastepaper, including $20 \%$ postconsumer waste 